\title{
Audit Committee Chair Attributes and Audit Report Lag in an Emerging Market
}

\author{
Ayad Ahmed Mohammed Al-Qublani ${ }^{1}$, Hasnah Kamardin ${ }^{1} \&$ Rohami Shafie ${ }^{1}$ \\ ${ }^{1}$ Tunku Puteri Intan Safinaz School of Accountancy, Universiti Utara Malaysia, Sintok, Malaysia \\ Correspondence: Ayad Al-Qublani, Tunku Puteri Intan Safinaz School of Accountancy, Universiti Utara Malaysia, \\ Sintok, Malaysia, 06010 Sintok, Kedah, Malaysia.
}

Received: April 6, 2020

Accepted: May 29, 2020

Online Published: July 8, 2020

doi:10.5430/ijfr.v11n4p475

URL: https://doi.org/10.5430/ijfr.v11n4p475

\begin{abstract}
This study is motivated by the new listing requirement of Bursa Malaysia (formerly known as Kuala Lumpur Stock Exchange, KLSE) concerning the shorter timeframe of annual report release. Similarly, the call for future research on the efficacy of audit committee chair (ACC) attributes with audit report lag (ARL) has further driven this study. Therefore, this paper aimed to analyse the relationship between the ACC expertise and ACC tenure with the ARL of companies in the Main Market of Bursa Malaysia in 2015 using a sample of 139 companies. Furthermore, other audit committee (AC) attributes such as AC overlap and AC independence were also examined. Results of the study revealed an average of 95 days is required by the companies to conclude their respective audit reports. ACC with accounting expertise enhanced the ARL, whereas AC overlap and AC independence did not reduce the ARL. Concurrently, other control variables like AC size, frequency of AC meetings, firm size, leverage, and profitability depicted significant relationship with the ARL. Hence, this research is relevant to the current ARL literature via the provision of evidence and justification regarding the important role of ACC with accounting expertise towards the AC effectiveness, thus enhancing the timelines of financial reporting.
\end{abstract}

Keywords: audit report lag, audit committee attributes, audit committee chair and accounting expertise

\section{Introduction}

Following the accounting scandals of various companies over the past few years, the quality of financial reporting has emerged as an issue of high importance. Such events included the collapse of Enron and ImClone Systems in 2001, and WorldCom and Tyco International in 2002 (i.e. in the United States of America (USA)) and Global Crossing in 2002 (i.e. in Europe) (Shafie, Wan-Hussin, Yusof, \& Hussain, 2009). Similar events occurring in Malaysia included Megan Media Holdings Berhad and Transmile Group Berhad in 2007 (i.e. in Malaysia) (Hasnan \& Hussain, 2015) and the recently explosive Felda Global Ventures Holdings Bhd (FGV) scandal of 2017. These collapses have highlighted the need to ameliorate the financial reporting quality (FRQ) and increase the transparency in the action undertakings (Bardos, 2011). In particular, one crucial metric of FRQ and transparency is timeliness (Al-Ajmi, 2008; Rusmin \& Evans, 2017) in which the timeliness of a financial report is seen as a critical attribute of financial accounting information (Al-Ajmi, 2008). This notion is attributable to its role in improving the usefulness and economic value of the information supplied (Apadore \& Mohd-Noor, 2013). More importantly, timely financial reporting will improve the confidence of investors (Leventis, Weetman, \& Caramanis, 2005) specifically by reducing any information asymmetry and enhancing the decision-making processes, predominantly in emerging markets including Malaysia (Owusu-Ansah \& Leventis, 2006).

The requirement of timely information for market participants in order to make investment decisions (Habib, Bhuiyan, Huang, \& Miah, 2019) has resulted in efforts towards enhancing financial reporting timeliness (Shin, Lee, Lee, \& Son, 2017). For example, Bursa Malaysia has reduced the timeframe for annual reports from six months to four months. Under this new requirement, companies were due to publishing their annual reports in no more than five months for a fiscal year-end on or after 31 December 2014. Following this, those for the fiscal year-end on or after 31 December 2015 were to be published in no more than four months from the fiscal year-end, whereby the timeframe for the audit reports remained four months (Bursa Malaysia 2013). According to Bursa Malaysia's then-Chief Executive Officer (CEO) Datuk Tajuddin Atan (2013), the new requirements would concurrently achieve the objective of improving the timeliness of annual report issuance and aligning its issuance timeframe in Malaysian 
companies with the practices of other markets. This would ensure that the investors receive financial information in a timely manner.

Consequently, the listing requirements detailed in Chapter 9 of Bursa Malaysia specify that the annual report of a company should include an auditor's report. As such, they are unable to release the annual report until external auditors have verified the financial statements. An auditor's report can improve the level of user confidence towards the financial statements presented as it specifies their opinions regarding the document's credibility (Habib \& Muhammadi, 2018; Salleh \& Jasmani, 2014). Moreover, an auditor-verified financial statement will eliminate any problems arising from a conflict of interest between owners and managers, which generally occurs in a situation in which one party of an enterprise has either more or better information than its counterpart (Varici, 2013). Thus, investors generally prefer shorter reporting lags in order to adjust their investment preferences (Habib et al., 2019). As a result, more pressure is exerted on an external auditor for them to finalise an audit and subsequently deliver the report without hold-ups (Sultana, Singh, \& Van der Zahn, 2015).

The failure to submit audited financial reports in a timely manner may affect the usefulness of the information supplied to those who use the financial statements, which in turn would diminish the economic value of the information (Al-Ajmi, 2008). Thus, any decisions made according to the financial statement information are potentially impacted by a delay in information release (Carslaw \& Kaplan, 1991). However, according to the CG Watch 2016 Report, "Malaysia is slightly behind on providing audited financial statements. Malaysian-listed companies have four months to produce their audited financials (published in an annual report) rather than the standard three months in other markets" (CLSA and ACGA, 2016). Furthermore, prior studies have shown that in Malaysia, the average ARL is 100 days as opposed to an average of between a minimum of 40 days to a maximum of 80 days in other developed and developing nations (Baatwah, Salleh, \& Stewart, 2019; Mohamad-Nor, Shafie, \& Wan-Hussin, 2010; Wan-Hussin, Bamahros, \& Shukeri, 2018). Therefore, improvements in ARL can pose a notable impact on the timeliness of the audited financial reports (Dong, Robinson, \& Xu, 2018), thereby leading to their enhanced timeliness in issuance. Besides, such improvements are an important step for orienting the investors in the direction of superior resource allocation choices, thus improving market efficiency (Khlif \& Samaha, 2014).

Many researchers have reported that a timely release of auditor reports is related to the length of the ARL itself (Ashton, Willingham, \& Elliott, 1987; Bamber, Bamber, \& Schoderbek, 1993; Blankley, Hurtt, \& MacGregor, 2014; Chan, Luo, \& Mo, 2016; Dong et al., 2018; Habib \& Muhammadi, 2018; Leventis et al., 2005). Therefore, the time spent by auditors on their work can be an extremely influential factor towards the timeliness of earnings information release to the market (Habib \& Muhammadi, 2018; Lee, Mande, \& Son, 2009). Given the possible negative effects of a delay in audit report issuance by companies, comprehending the potential causal factors of the ARL poses the likelihood of insight provision into audit efficiency (Lee et al., 2009). It may also generate information that is useful in aiding researchers and practitioners towards designing solutions for lag reduction (Durand, 2019).

Nowadays, many AC charters have specifically underline timeliness as a responsibility of the AC. Notably, an ACC plays an important role in this responsibility (Abernathy, Beyer, Masli, \& Stefaniak, 2015). It is achieved by ensuring the proper flow of information to the $\mathrm{AC}$ and maintaining an open association between the $\mathrm{AC}$, the management, and the internal and external auditors accordingly (Abernathy, Beyer, Masli, \& Stefaniak, 2014). Furthermore, Ghafran and Yasmin (2018) have confirmed that the chair of the AC itself is highly essential in upholding the committee's capability towards achieving its responsibilities effectually. Udueni (1999) has regarded the chairman of a major board committee such as the $\mathrm{AC}$ as a more influential person in comparison with other members who are not at the helm of any committee. Therefore, the chairperson has more responsibilities than other members to account for in cases of financial reporting failures. As the performance of $\mathrm{AC}$ members is critically influenced by the position of its chairman (Al-Absy, Ismail, \& Chandren, 2019), knowledge of their attributes can further enhance the effectiveness of the AC and subsequently improve financial reporting timeliness (Ghafran \& Yasmin, 2018).

Prior researches have shown that accounting experts are the most influential party in elevating the AC's monitoring role (Carcello, Hollingsworth, Klein, \& Neal, 2006; Dhaliwal, Naiker, \& Navissi, 2010; Krishnan \& Visvanathan, 2008). According to DeFond, Hann, and Hu (2005), accounting knowledge may be highly crucial for AC members than any other forms of expertise as they are responsible for the tasks requiring high degree of accounting sophistication. Consequently, knowledge of AC member can enhance the efficiency of the AC in keeping track of the financial reporting process (Abbott, Parker, \& Peters, 2004; Abernathy et al., 2014; Krishnan \& Visvanathan, 2008; Sultana et al., 2015; Sultana \& Van der Zahn, 2015), thereby improving the financial reporting timeliness (Ghafran \& Yasmin, 2018). Moreover, Abernathy et al. (2014) and Baatwah, Salleh, and Ahmad (2016) have argued that AC members equipped with accounting expertise can minimise the actual amount of time required for the AC to 
adequately discuss, completely understand and assess the accounting policies and peculiar transactions with the auditor. However, merely a small number of published works in Malaysia have empirically looked into the role of the ACC on ARL. In Malaysia, Baatwah et al. (2019) are the only researchers who have explored the association between the ACC who has the accounting expertise and ARL. Regardless, the current work is essentially an extension of Baatwah et al. (2019), but with some differences. Baatwah et al. (2019) utilised the top 100 listed companies in 2011, which might earn some worry about their findings' generalisation to the smaller companies listed on Bursa Malaysia. However, the current study tries to fill this gap by extending the sample and using the year of study immediately after the introduction of the new requirement to produce an audit report within four months. Additionally, the current study is a response to Habib et al.'s (2019) recommendation for future works to identify the role of the ACC on ARL. Hence, this study provides further evidence of the effect of ACC attributes on ARL in Malaysia.

The remaining content of the current paper is sectioned as such: section two appraises the corporate governance practices in Malaysia, while the third section details a literature review and developing a hypothesis. Then, the fourth section explicates the research design implemented, while an ensuing discussion on the findings and their analysis follows. The final section details a comprehensive conclusion by summarising the findings and suggesting the opportunities for future study findings.

\section{Corporate Governance in Malaysia}

A series of fiscal crises over the years in Asian countries has thus revealed a lack of transparency and a weakened financial system. The governments of these countries have thus embarked on improving their financial systems to restore the confidence that had been lost (Vichitsarawong, Eng, \& Meek, 2010). The financial crisis in 1997, in particular, clearly indicated weaknesses in the Malaysian corporate governance, which led to an overhaul of its entire corporate sector (Singam, 2003). The country's primary mainstay of corporate governance reformation agenda is hinged upon the Malaysian Code on Corporate Governance (MCCG) (Ponnu, 2008). From 1998 onwards, the Malaysian government began the processes, thereby establishing an important financial committee to develop a standard framework for corporate governance and delineating the optimal practices for Malaysian companies.

The first MCCG issuance occurred in March 2000, which signified a corporate governance reform in the country. The code consisted of three sections (Securities Commission, 2000), namely: the principles of corporate governance, the best practices in corporate governance, and the principles and best practices for other corporate participants. The critical elements in corporate governance were comprehensively highlighted by the code, specifically addressing the issues related to shareholders, board of directors, accountability, and audit. Furthermore, the code enunciated risk management as one of the key responsibilities of the board of directors (Ghazali \& Manab, 2013). In 2001, the aftermath of the KLSE listing requirements revamps rendered the code effective for all publicly listed companies. Consequently, all public companies are required to adhere to Chapter 15 of the code, which is related to the directors, AC, auditors, and corporate governance disclosure (Kamardin \& Haron, 2011).

The complexity of the capital market and the need to enhance corporate governance practice collectively resulted in the code to be revised in 2007 (Mohamad-Nor \& Ishak, 2017). In 2007, the major amendments of MCCG (Revised MCCG 2007) made to the code specifically emphasised on strengthening the board of directors and the AC, as well as making sure that both elements effectively discharged their responsibilities and roles. Moreover, the revised code provided criteria for the candidates of the directorship, which included the skills, experience, knowledge, integrity, professionalism, and inherent ability of the directors to effectively discharge their expected responsibilities (Kamardin \& Haron, 2011).

MCCG (Revised 2007) stated that AC should be consisting of a minimum of three members drawn from the board of directors. Then, the members should be non-executive directors, whereby most of them should be independent directors. Furthermore, the code recommended for the AC members to own financial expertise and a minimum of one member is recommended to be from an accounting body or association.

In 2012, another code revision was introduced in which the main aim of MCCG 2012 was to improve the MCCG and its internal mechanisms. The new code concentrated on explaining the important roles that the board would undertake in providing meaningful leadership and improving its overall effectiveness. Besides, the code was aimed at reinforcing the director independence by limiting the period of service of every independent director to a maximum of nine years. Additionally, it stated that the bulk of the directors on the board of directors should be independent in case the present chairman was not independent. The MCCG 2012 contained eight distinct principles, the main focus of which was to lay a strong and formidable foundation for the entire board and its appointed committees to effectively enhance their roles. Concurrently, the code will safeguard the overall integrity associated with financial 
reporting and ensure a timely and high-quality disclosure that underlines the risk management and internal controls by establishing a sound framework for managing risks (MCCG 2012).

In April 2016, the proposed draft of the MCCG was introduced by the Securities Commission (SC). One of the main suggestions included reinforcing the role of the ACC, whereby it should be capable of fully committing and exercising an independent judgment (Al-Absy et al., 2019). According to Principle B, Practice 7.2, companies must employ an AC chairman who has accounting experience. Then, in 2017, the SC released the revised MCCG 2017 with the principal aim of strengthening the internalisation of a good corporate governance culture, with an added emphasis on accountability and transparency. The MCCG 2017 comprised of three principles, namely audit and risk management, a board of directors, and integrity in corporate reporting. It stated that the board of directors must consist of independent directors for large companies at least by half. The code also called for independent directors only on the AC and that the ACC should not be the chairman of the board of directors. Additionally, the code also emphasised the need for strong internal control and risk management functions (MCCG 2017). However, the recommendation of the drafted MCCG (2016) did not concur with MCCG 2017, which stated that the ACC is required to have accounting or relevant experiences.

\section{Literature Review and Hypothesis Development}

\subsection{Previous Studies on Audit Report Lag}

The period of time between the fiscal year-end and the audit report date is generally referred to as the ARL (Ashton et al., 1987; Habib et al., 2019; Wan-Hussin et al., 2018). Most of the earlier studies have measured ARL as the total number of days starting from the fiscal year-end to the audit report date (Durand, 2019; Ghafran \& Yasmin, 2018; Habib, 2015; Leventis et al., 2005; Wan-Hussin et al., 2018). Furthermore, it has been shown to impact the timeliness of earnings announcement (Givoly \& Palmon, 1982), is the cause of auditor switching (Mande \& Son, 2011), and result in restatements and non-standard opinions in the following years (Chan et al., 2016). Timing of publication of an audit report is thus a crucial element for investment decision-making (Habib et al., 2019). In fact, a delay in disclosing an auditor's opinion on financial information is a bad signal of irregularity or fraud among managers and shareholders, thereby causing both current and potential investors to lose their confidence in a financial report (Apadore \& Mohd-Noor, 2013; Leventis et al., 2005; Mohamad-Nor et al., 2010). Therefore, investors mostly prefer short ARL (Habib et al., 2019).

The importance of ARL has encouraged previous researchers to analyse several factors that may affect its extent (Kaaroud, Mohd Ariffin, \& Ahmad, 2020). Durand (2019) has reported that out of 126 independent variables used in previous studies as the determinants of ARL, they can be divided into three categories, namely: firm attributes, audit attributes, and corporate governance attributes. Studies on firm attributes have largely focused on the firm complexities in which larger companies arguably have strong internal control systems, which lead to a shorter ARL (Ashton, Graul, \& Newton, 1989; Givoly \& Palmon, 1982). Furthermore, the number of subsidiaries is used as a proxy for the complexity; as the number of subsidiaries increases, the ARL is also likely to increase (Durand, 2019; Lee \& Jahng, 2011; MohammadRezaei \& Mohd-Saleh, 2018; Rusmin \& Evans, 2017; Xu, Carson, Fargher, \& Jiang, 2013).

Besides, a firm's financial year influences the audit delay (Ashton et al., 1989; Ashton et al., 1987). The studies have particularly reported that companies with their year-end falling within the peak season will have a longer ARL. Meanwhile, other determinants of ARL analysed are the performance and financial condition of issuers. Accordingly, Givoly and Palmon (1982) and Courtis (1976) both have detailed empirical evidence showing that bad news usually takes a longer duration before reaching the public compared to the good news. Similarly, Ashton et al. (1989), Bamber et al. (1993), and Carslaw and Kaplan (1991) have revealed that an audit report is delayed when a loss is reported. However, Dyer and McHugh (1975) have perceived no correlation linking total reporting lag and profitability in Australia. Moreover, leverage is another measure of organisational risk already utilised in several studies (Habib et al., 2019). Highly leveraged companies have been found to possess a longer audit lag period than less leveraged companies (Al-Ajmi, 2008; Bamber et al., 1993; Habib et al., 2019).

Furthermore, the industry classification of a firm seems to have an important role in ARL, whereby having a lower ARL tends to be common among the financial industries (Ashton et al., 1987; Courtis, 1976). Similarly, Al-Ajmi (2008) has reported that banks have a shorter audit lag, whereas Xu, Dao, and Petkevich (2019) have recently examined political corruption and its effect on auditor behaviour. They have found that companies in the USA with headquarters located in highly corrupt areas have a longer ARL. This indicates that trustworthiness and client risks are assessed by auditors based on where the headquarters of companies are located. In contrast, the Indonesia-based study by Habib and Muhammadi (2018) has shown that a shorter ARL is associated with companies with political 
connections. In addition, related party transactions by companies with such political connections have an incremental effect on the ARL of a firm, which suggests that audit risk increases related party transactions as a result of their opportunistic nature.

Besides firm attributes, several studies have shown that auditor attributes are associated with ARL, such as audit fees (Swanson \& Zhang, 2018), auditor opinion (Chan et al., 2016; Durand, 2019; Raja-Ahmad \& Kamarudin, 2003; Soltani, 2002), auditor change (Swanson \& Zhang, 2018; Xu et al., 2013), busy auditors (Wan-Hussin et al., 2018), audit partner rotation (Sharma, Tanyi, \& Litt, 2017), Big-4 consulting (Meckfessel \& Sellers, 2017), audit risk (Chan et al., 2016), type of audit firm (Gilling, 1977; Lee \& Jahng, 2011; Rusmin \& Evans, 2017; Xu et al., 2013), audit firm industry specialisation (Habib \& Bhuiyan, 2011; Rusmin \& Evans, 2017), high non-audit fees (Knechel, Sharma, \& Sharma, 2012), and auditor-client geographic proximity (Dong et al., 2018).

With the growing interest in corporate governance, a surge in research is seen on the correlation between the different attributes of corporate governance and ARL (Bhuiyan \& D'Costa, 2020). Empirical studies have thus had to contend that firm ownership may potentially affect ARL (Bamber et al., 1993; Carslaw \& Kaplan, 1991; Habib \& Bhuiyan, 2011; Mohammad-Rezaei \& Mohd-Saleh, 2018; Soltani, 2002). Furthermore, Che-Ahmad and Abidin (2008) have correlated a higher director interest in the firm with a higher audit delay. This indicates the significant role played by ownership structure in the ARL. Similarly, prior studies have viewed ARL as a complete reflection of the internal and external efforts of the auditors. In particular, internal audit assistance is found to be negatively correlated with ARL (Abbott, Parker, \& Peters, 2012), whereas Wan-Hussin and Bamahros (2013) have underlined the negative correlation linking ARL with internal audit function costs. Nevertheless, Apadore and Mohd-Noor (2013) have revealed that investment in the internal audit functions does not play any role in improving the timeliness of audit report.

Next, board attributes have been a subject of lengthy discussion in terms of their correlation to ARL. Previous studies have thus shown that board independence (Afify, 2009; Alfraih, 2016; Daoud, Ismail, \& Lode, 2015), board meetings, board size (Ahmed \& Che-Ahmad, 2016; Daoud et al., 2015), board gender (Ahmed \& Che-Ahmad, 2016) and board leadership, and differentiating the roles of the CEO and board chairman (Abdullah, 2006; Afify, 2009; Alfraih, 2016) to yield a significant effect on ARL. In fact, $\mathrm{AC}$ as an important sub-committee is responsible for overseeing all auditing and financial reporting-related matters of a company (Bhuiyan \& D'Costa, 2020). Further evidence from ARL literature also indicates that the independence level of the AC (Sultana et al., 2015) and its financial expertise (Oussii \& Taktak, 2018; Raweh, Kamardin, \& Malik, 2019; Sultana et al., 2015) influence ARL. In contrast, AC size (Sultana et al., 2015), gender variable (Sultana et al., 2015), AC authority (Oussii \& Taktak, 2018), and meetings (Oussii \& Taktak, 2018; Raweh et al., 2019; Sultana et al., 2015) do not appear as significant determinants with ARL.

The combination of global corporate governance reforms, the latest legislation, and other best practices guidelines introduced in prior decades have augmented the AC's roles and responsibilities throughout financial reporting (Sultana et al., 2015). Given such responsibility and the nature and complexity of financial reporting itself, governance regulators worldwide have made their interest shown in AC members who have the expertise (Ghafran \& Yasmin, 2018). For example, the Sarbanes-Oxley Act of 2002 (SOX) reinforces the significance of having a financial expert on the AC (Tanyi \& Smith, 2015), while the Malaysian MCCG 2017 suggests that its every member should have adequate financial knowledge. In view of this, ACC plays a crucial role in buttressing the committee ability towards achieving its responsibilities effectively (Abernathy et al., 2015; Ghafran \& Yasmin, 2018; Schmidt \& Wilkins, 2013).

Given the possible effects of ARL in the timeliness of issuing annual reports (Wan-Hussin \& Bamahros, 2013), a sizeable number of studies have reported on examining the factors leading to audit report delay (Bhuiyan \& D'Costa, 2020; Juwita, T, \& Hariadi, 2020; Kaaroud et al., 2020). However, limited studies have been done on the importance of ACC attributes, such as accounting expertise and ACC tenure (i.e., Baatwah et al., 2019; Ghafran \& Yasmin, 2018; Tanyi \& Smith, 2015). Therefore, the current study is a response to the call by Habib et al. (2019) to conduct further investigation on the influence of ACC attributes in ARL.

\subsection{Expertise of Audit Committee Chair}

The existence of $\mathrm{AC}$ members equipped with financial expertise increases the committee capability, namely by ensuring the external auditor's function is carried out competently (Sultana et al., 2015). From the agency theory and resource dependency perspective, directors holding specific knowledge and expertise provide relevant resources, such as advice to enhance the monitoring of a firm's financial processes (Hillman \& Dalziel, 2003). Therefore, AC members with accounting expertise further enhance its efficacy in overseeing the financial reporting process (Abbott et al., 2004; Abernathy et al., 2014; Krishnan \& Visvanathan, 2008; Sultana et al., 2015; Sultana \& Van der Zahn, 
2015).

Empirical evidence detailing the relationship between ACC expertise and audit quality have been obtained by various researchers, such as Abernathy et al. (2014), Baatwah et al. (2019), Ghafran and Yasmin (2018), and Schmidt and Wilkins (2013). An ACC with the right financial expertise can enhance the power of the AC and improve its monitoring role (Baatwah, Ahmad, \& Salleh, 2013). Furthermore, Schmidt and Wilkins (2013) have concluded that the ACC with accounting financial expertise can provide the timeliest disclosures, whereby the AC with such expertise may be better positioned to render their assistance to the management and internal auditors in the event of financial reporting issues. The presence of an $\mathrm{AC}$ with financial expertise may enable the committee members to allocate their time and resources appropriately and ensuring any misstatement is corrected in a timely manner. Besides, they have revealed that the restatement periods are shorter for clients having AC members with more accounting expertise.

Consistent with such view, Abernathy et al. (2014) and Baatwah et al. (2016) have indicated that an ACC with accounting expertise is correlated negatively and significantly with the ARL. They have further argued that AC members equipped with the required accounting expertise can minimise the actual length of time required for the AC to adequately scrutinise and clearly understand and assess key accounting policies and normal transactions with the auditor. However, Ghafran and Yasmin (2018) have found that an ACC equipped with financial expertise is insignificantly related to ARL. Thus, by underpinning the agency theory and resource dependency perspective, the following hypothesis is made:

H1: There is a negative relationship between ACC with accounting expertise and ARL.

\subsection{Tenure of Audit Committee Chair}

Tenure can be described as the length of time that a member has served on the board (Al-Absy et al., 2019; Ghafran \& Yasmin, 2018; Kesner, 1988). The tenure of AC directors who are on the board is a notable feature in determining the actual efficiency of ACs in performing their expected monitoring role. Prior scholars have differing notions regarding the effect of $\mathrm{AC}$ member tenure on the capability to monitor the financial reporting process. Available literature detailing job performance has indicated that the time invested in an entity can enhance one's competency in undertaking their duties accordingly (Steffens, Shemla, Wegge, \& Diestel, 2014). Directors with longer tenure will also develop expertise, reputation, and experience in a specific field (Liu \& Sun, 2010). Furthermore, AC members having a longer tenure are expected to effectively monitor company operation and produce high-quality financial reporting (Herranz, Iturriaga, \& Reguera-Alvarado, 2018; Rickling, 2014; Thoopsamut \& Jaikengkit, 2009).

Previous studies have examined the influence of tenure on the FRQ. Chan, Liu, and Sun (2012) have argued that the longer the tenure of AC members, less audit effort will be demanded as a result of effective monitoring conducted. Furthermore, Liu and Sun (2010), Thoopsamut and Jaikengkit (2009), and Yang and Krishnan (2005) have found that the FRQ is higher when AC members have a longer tenure, arguing that directors with long tenure provide effective monitoring because of their knowledge and experience in the task. More recently, Herranz et al. (2018) have found a non-linear relation with AC tenure and the quality of financial information, detailing that long tenure can initially compromise the independence of directors. However, after a certain threshold, then longer tenure improves the expertise of committee members.

Nevertheless, other research suggests that the directors' independence may be affected over time as directors form associations with each other (Byrd, Cooperman, \& Wolfe, 2010). Those with long tenure are more likely to have a friendly relation with managers (Rickling, 2014), which will impair their willingness to carry out effective monitoring of the financial reporting process. Importantly, extant research has shown the positive effect of a board with a long tenure on FRQ, which is more dominant than the negative effect (Chan et al., 2012; Ghafran \& Yasmin, 2018).

Regarding ARL, only a few studies have explored the association between tenure of ACC and ARL. For instance, Abernathy et al. (2014) have reported a significantly negative effect linking AC members with longer tenure and ARL. This result is consistent with Ghafran and Yasmin (2018), who note that an ACC with a long tenure in a firm is associated with experience gained over a period of time, which helps in reducing the ARL. Similarly, Baatwah, Salleh, and Ahmad (2015) have noted that the director's tenure is directly associated with a timely audit report. It is important to note that tenure increases a director's familiarity and correlation with a firm's financial reporting processes and enables an external auditor to begin their work early and complete the audit in a short time. Baatwah et al. (2019) have reported a negatively significant correlation linking the tenure of the ACC with ARL. Thus, this is suggesting of possibility for the AC chair tenure towards improving the ACC's knowledge and experience on the financial reporting processes of any firm and industry-specific accounting issues. Based on the arguments presented above and available empirical findings, this work positions the following hypothesis: 
$\mathrm{H} 2$ : There is a negative between tenure of ACC and ARL.

\subsection{Audit Committee Overlap}

AC plays an important capacity in the process of firm financial reporting and has emerged the main subject of corporate governance reforms, especially following various accounting scandals worldwide. In particular, previous literature has studied AC attributes such as AC independence, AC size, AC meetings, AC qualification, and AC financial expertise, but neglect the element of overlap as one of the attributes that can influence the effectiveness of the AC members. There are two conflicting perspectives in the literature when examining the implications of overlapping AC memberships. Firstly, overlapping membership of the AC with the compensation committee is likely to bring knowledge spillover, namely an essential component for the AC's financial reporting oversight function (Chandar, Chang, \& Zheng, 2012). Habib and Bhuiyan (2016) have provided supporting evidence on the positive relationship between overlapping membership on audit and compensation committees with the FRQ. Furthermore, Velte (2017) has found that AC members concurrently have a seat in the compensation committee contribute to increasing the FRQ as a proxy of accrual quality. These findings suggest that the AC overlap produces higher FRQ.

In contrast, other researchers argue that $\mathrm{AC}$ members who exist on other committees (e.g. compensation committee) may render them overcommitted, thus yielding a reduced effectualness as the monitors of financial reporting (Liao \& Hsu, 2013). Such notion is consistent with the busyness hypothesis, which states that AC monitoring is weakened when the members are preoccupied with other works (Tanyi \& Smith, 2015). Furthermore, Liao and Hsu (2013) have found that companies with a common membership yield poorer earning quality and less pay-performance sensitivity than other companies. Accordingly, Rickling (2014) argues that the degree of director busyness can influence the AC member's effectiveness in order to provide effective financial reporting oversight and call for governance advocates and other parties to limit AC members sit on many committees. Similarly, Kusnadi, Leong, Suwardy and Wang (2016) have not perceived the effect of overlapping membership towards the audit and remuneration committees on FRQ.

Few studies focused on the relationship between AC overlap and ARL such as Ghafran and Yasmin (2018) have found that an ACC sitting on multiple committees can improve the financial reporting timeliness and reduce the ARL period. By serving on several monitoring committees, they are more likely to have a complete and detailed understanding of a firm, thus enhancing their overall ability to make a sound and better-informed decisions (Chandar et al., 2012). Based on the arguments presented above, this work positions the following hypothesis:

H3: There is a relationship between AC overlap and ARL.

\subsection{Audit Committee Independence}

Independent directors generally undertake a crucial capacity in supervising the managerial aspect and enhancing the efficiency of the Board (Abbott, Park, \& Parker, 2000; Abdul Latif, Kamardin, Taufil Mohd, \& Che Adam, 2013; Bedard, Chtourou, \& Courteau, 2004). Accordingly, the agency theory and resource dependence theory both have argued that the larger proportion of external directors on the board is linked to a lesser likelihood of being compromised upon carrying out the sub-committee's roles and responsibilities (Sultana et al., 2015). Therefore, they are likely to enhance committee effectiveness and supervisory functions in financial reporting (Hashim \& Rahman, 2011; Song \& Windram, 2004). Moreover, independent AC assists in balancing the disparate viewpoints of external and internal auditors in order to generate a financial report of higher quality (Kusnadi et al., 2016). Consequently, the activity and roles undertaken by a more independent $\mathrm{AC}$ are highly linked to a reduced time required to issue the audit report (Oussii \& Taktak, 2018). However, the companies with independent ACs may necessitate their auditors to carry out extra audit efforts so as to identify possibilities of misstatements (Habib \& Muhammadi, 2018), thereby increasing ARL.

Previous studies have analysed the relationship between AC independence with ARL but most of their findings remain inconclusive. For example, Sultana et al. (2015) have revealed the negative association linking independent ACs and ARL, whereas Oussii and Taktak (2018) and Raweh et al. (2019) have failed to find notable correlation linking the two elements. In the context of Malaysia, Wan-Hussin and Bamahros (2013) and Baatwah et al. (2019) have also identified a significantly negative association linking AC independence and ARL, while contrastingly, Mohamad-Nor et al. (2010) and Wan-Hussin et al. (2018) have stated that AC independence is not significantly related to ARL. Following the perspectives of the agency theory and resource dependence theory, the following hypothesis is put forward:

$\mathrm{H} 4$ : There is a negative relationship between AC independence and ARL. 


\section{Research Methodology}

\subsection{Sample}

The study used secondary data gathered from the annual reports of non-financial companies at Bursa Malaysia Main Market (www.bursamalaysia.com) for the year 2015. Annual reports of 2015 were specifically chosen based on the proposed MCCG draft 2016 related to the potential of ACC in enhancing corporate governance. Currently, 744 non-financial companies are listed on the Main Market. As such, the samples were chosen randomly (i.e. $20 \%$ from each industry sector) out of 729 companies after excluding PN17 or distressed companies. Therefore, the initial sample consists of 146 listed companies as described in Table 1. However, the final sample of the study was 139 companies due to some missing observations.

Table 1. Sample of study

\begin{tabular}{lcccc}
\hline Sector & $\begin{array}{c}\text { All non-financial } \\
\text { companies on Main } \\
\text { Market }\end{array}$ & PN17 companies & $\begin{array}{c}\text { Number of } \\
\text { companies } \\
\text { available }\end{array}$ & $\begin{array}{c}\text { Sample of } \\
\text { study }\end{array}$ \\
\hline Consumer Products & 124 & 5 & 119 & 24 \\
\hline Industrial Products & 220 & 6 & 214 & 42 \\
\hline Construction & 46 & 0 & 46 & 9 \\
\hline Trading-Services & 188 & 4 & 184 & 37 \\
\hline Technology & 30 & 0 & 30 & 6 \\
\hline Properties & 95 & 0 & 95 & 9 \\
\hline Plantation & 41 & 0 & 41 & 146 \\
\hline Total companies & 744 & 15 & 729 & \\
\hline
\end{tabular}

\subsection{Model Specification}

To test the hypotheses and relationship between the dependent variable and independent variables, this work opted for multiple regression analysis. Based on previous studies, this study proposed that the expertise of ACC, tenure of ACC, AC overlap, and AC independence variables, inclusive of the control variables, to influence the ARL. The measurements of the variables are summarised in Table 2. The model specification was built based on the previous models employed by prior researchers (Afify, 2009; Al-Ajmi, 2008; Ashton et al., 1987; Baatwah et al., 2019; Habib \& Muhammadi, 2018; Leventis et al., 2005; Sultana et al., 2015; Wan-Hussin et al., 2018). The ARL model is depicted below:

$\mathrm{ARL}=\beta 0+\beta 1$ ACCEXP $+\beta 2$ ACCTENURE $+\beta 3$ ACOVLAP $+\beta 4$ ACIND $+\beta 5$ ACSIZE $+\beta 6$ ACMEET $+\beta 7$ TYPEAUD $+\beta 8$ SIZE $+\beta 9$ LEV $+\beta 10$ PROF $+\beta 11$ INDUS $+\varepsilon$.

Table 2. Summary of measurements of the variables

\begin{tabular}{|c|c|c|c|c|}
\hline Variables & $\begin{array}{l}\text { Variable } \\
\text { Name }\end{array}$ & Measurement & $\begin{array}{l}\text { Expected } \\
\text { Correlation }\end{array}$ & Sources of Measures \\
\hline $\begin{array}{l}\text { Audit report } \\
\text { lag }\end{array}$ & ARL & $\begin{array}{l}\text { The number of days between the } \\
\text { date of the financial year-end and the } \\
\text { date of the auditor's report. }\end{array}$ & - & $\begin{array}{l}\text { (Afify, 2009; Ashton et al., } \\
\text { 1989; Kaaroud et al., } \\
\text { 2020; Wan-Hussin et al., } \\
\text { 2018). }\end{array}$ \\
\hline $\begin{array}{l}\text { Expertise of } \\
\text { AC chair }\end{array}$ & ACCEXP & $\begin{array}{l}\text { Dummy variable, " } 1 \text { " if the ACC is } \\
\text { qualified as an accounting and } \\
\text { auditing expertise, and " } 0 " \text { if } \\
\text { otherwise. }\end{array}$ & Negative & $\begin{array}{l}\text { (Abernathy et al., 2014; } \\
\text { Baatwah et al., 2019; } \\
\text { Ghafran \& Yasmin, 2018; } \\
\text { Schmidt \& Wilkins, 2013). }\end{array}$ \\
\hline $\begin{array}{l}\text { Tenure of AC } \\
\text { chair }\end{array}$ & ACCTENURE & $\begin{array}{l}\text { Number of years that ACC was } \\
\text { appointed in the board. }\end{array}$ & Negative & $\begin{array}{l}\text { (Al-Absy et al., 2019; } \\
\text { Ghafran \& Yasmin, 2018; } \\
\text { Tanyi \& Smith, 2015). }\end{array}$ \\
\hline
\end{tabular}




\begin{tabular}{|c|c|c|c|c|}
\hline Variables & $\begin{array}{l}\text { Variable } \\
\text { Name }\end{array}$ & Measurement & $\begin{array}{l}\text { Expected } \\
\text { Correlation }\end{array}$ & Sources of Measures \\
\hline AC overlap & ACOVLAP & $\begin{array}{l}\text { Number of AC members serving in } \\
\text { both the audit and remuneration } \\
\text { committees divided by the number } \\
\text { of AC size }\end{array}$ & $\begin{array}{l}\text { Positive/ } \\
\text { Negative }\end{array}$ & (Karim et al., 2016). \\
\hline $\begin{array}{l}\mathrm{AC} \\
\text { independence }\end{array}$ & ACIND & $\begin{array}{l}\text { Proportion of independent AC on the } \\
\text { total number of AC size. }\end{array}$ & Negative & $\begin{array}{l}\text { (Mohamad-Nor et al., } \\
\text { 2010; Wan-Hussin et al., } \\
\text { 2018). }\end{array}$ \\
\hline AC size & ACSIZE & Number of AC members & Negative & $\begin{array}{l}\text { (Wan-Hussin \& Bamahros, } \\
\text { 2013; Wan-Hussin et al., } \\
\text { 2018). }\end{array}$ \\
\hline AC meeting & ACMEET & $\begin{array}{l}\text { The total number of AC meetings } \\
\text { during the financial year. }\end{array}$ & Positive & (Wan-Hussin et al., 2018). \\
\hline Auditor type & TYPEAUD & $\begin{array}{l}\text { Dummy variable, "1" if the auditor } \\
\text { from Big } 4 \text { and " } 0 \text { " otherwise. }\end{array}$ & Negative & $\begin{array}{l}\text { (Habib et al., 2019; } \\
\text { Wan-Hussin et al., 2018). }\end{array}$ \\
\hline Firm Size & SIZE & $\begin{array}{l}\text { The natural logarithm of the total } \\
\text { assets of the firm }\end{array}$ & Negative & $\begin{array}{l}\text { (Afify, 2009; Wan-Hussin } \\
\text { et al., 2018). }\end{array}$ \\
\hline Leverage & LEV & Total debts divided by total assets. & Positive & $\begin{array}{l}\text { (Habib et al., 2019; Lee \& } \\
\text { Jahng, 2011). }\end{array}$ \\
\hline Profitability & PROF & Net income to total assets & Negative & $\begin{array}{l}\text { (Afify, 2009; Ghafran \& } \\
\text { Yasmin, 2018; Habib et } \\
\text { al., 2019). }\end{array}$ \\
\hline Industry & INDUS & The industry dummies & - & $\begin{array}{l}\text { (Ghaleb, Kamardin, \& } \\
\text { Tabash, 2020). }\end{array}$ \\
\hline
\end{tabular}

\section{Data Analysis and Findings}

\subsection{Descriptive Statistics}

Descriptive statistics are summarised in Table 3 accordingly. The results showed the mean for ARL for Malaysian listed companies as 95 days: this meant that the time required by the external auditors of listed companies to conclude their audit work was 95 days on average, with a minimum of 45 days and a maximum of 122 days. This result is approximately similar to previous studies in Malaysia (see Apadore \& Mohd-Noor, 2013; Wan-Hussin \& Bamahros, 2013). Therefore, the time required to produce an audit report is within the time given, namely a maximum of four months. However, five companies $(3.60 \%)$ still produced reports over more than four months and not complying with the requirements. In comparison with other studies, the ARL in Malaysia is lengthier in duration compared to other developing and developed countries. For example, developed countries have ARL that is less than 90 days; Abbott et al. (2012) have noted that the average ARL in USA companies is 65.69 days, Australian companies is 80.67 days (Sultana et al., 2015), the UK companies is 63.84 days (Ghafran \& Yasmin, 2018), and New Zealand companies is 61 days (Habib \& Bhuiyan, 2011). Almost all organised stock exchanges are bound by comparable or much rigorous reporting and filing requirements (Kamarudin, Ismail, Yaacob, \& Bakar, 2018). In contrast, more studies have shown that the average ARL in other developing countries is less than Malaysia. For instance, it took 84.34 days for companies in China (Chan et al., 2016), 52.9 days for Korean companies (Shin et al., 2017), and 78.43 days for Indonesian companies (Habib \& Muhammadi, 2018). Similarly, Arab countries yield similar numbers, such as Egypt with 67.21 days (Afify, 2009), Oman with 52.34 days (Baatwah et al., 2015), Kuwait with 65.26 days (Alfraih, 2016), Palestine with 62.4 days (Hassan, 2016), and Jordan with 68.01 days (Daoud et al., 2015). The potential factors may be due to the requirements to produce audit report in the other countries that are shorter than Malaysia, whereby the companies located in most of the developed countries have to produce audit reports within three months. The same goes to other companies in the Middle-East countries or developing countries, which follow the international standard of within three months. This is the reason for the longer ARL in Malaysia 
compared to other countries, which means that a lengthier time frame is required to release the annual reports to the public.

Table 3 depicts the descriptive statistics of the independent and control variables employed in this particular work. Results showed that the fraction of companies having ACC with accounting expertise in the sample was 65.5 per cent. This is a good indicator of the extent of the proposed law application per the SC (i.e. proposed draft MCCG 2016), which has suggested that the ACC should be a person with accounting expertise. Furthermore, this outcome parallels the findings from Al-Absy et al. (2019), who have found that 66.44 per cent of the ACC have accounting expertise. Meanwhile, the average number of years that ACC held the position in the firm was 8.542 years, with the minimum and maximum tenure of 0.070 and 22.280 years, respectively, thus being similar to the results obtained by Baatwah et al. (2019) and Al-Absy et al. (2019). Moreover, the mean of AC overlap was 0.691, revealing that two-thirds or more of the sampled companies were associated with one director who sat on the remuneration committee and AC both at minimum. Results in Table 3 also show that about 90 per cent of the AC members are independent members. This is in line with Paragraph 15.9 of the listing requirement, which states that all AC members are required to be non-executive directors, a majority of which consisting of independent directors. This outcome is thus consistent with those of Wan-Hussin et al. (2018) and Hashim and Rahman (2011).

In the context of the control variables, the mean of $\mathrm{AC}$ size is three directors, which parallels previous studies (Apadore \& Mohd-Noor, 2013; Wan-Hussin \& Bamahros, 2013; Wan-Hussin et al., 2018). The minimum number of AC member was three, while the maximum number was six. The frequency of AC meetings was found to be on average of five times a year, whereas the maximum frequency of AC meetings held during the year was ten times. This suggests that most of the Bursa Malaysia companies have complied with the frequency of meeting requirement, which is a minimum of four times a year, whereas only a small portion of the sample has conducted it less than four times. Relatively speaking, more than half of the sample companies had more than five meetings per year, which indicated that the majority of the AC performed their responsibilities and duties effectively. This result is in tandem with the findings of Apadore and Mohd-Noor (2013) and Wan-Hussin et al. (2018) accordingly.

For the element of auditor type, the mean was 0.525 , indicating that about 53 per cent of the sampled companies commissioned the Big 4 for audits, while the remaining 47 per cent were audited by non-Big 4 . This result is in line with the results of AlQadasi, Abidin, and Al-Jaifi (2018), AlQadasi and Abidin (2018) and Ghaleb et al. (2020), who have reported that 52 per cent, 53 per cent and 54 per cent, respectively, of their sampled companies to be audited by Big 4 auditing entities. This suggests that Bursa Malaysia companies tend to hire more specialised and qualified auditors to guarantee quality audit and financial reports. The mean of firm size as computed by the natural $\log$ of total assets was 13.152, with the minimum and maximum sizes of 9.880 and 17.675 , respectively. This result is consistent with findings of empirical studies (e.g., Al-Absy, Ismail, \& Chandren, 2018; Qasem, Aripin, \& Wan-Hussin, 2020). In terms of leverage, the descriptive statistics indicated a mean of 0.194 , with a minimum value of zero and a maximum value of 0.724 . This shows a high leverage diversity between companies. Regarding firm profitability, it appeared that the ROA (PROF) on average was 0.052 , ranging from -0.496 to 0.379 .

Table 3. Descriptive statistics of variables

\begin{tabular}{lcccccc}
\hline Variable & Mean & Minimum & Maximum & Std. Deviation & Kurtosis & Skewness \\
\hline ARL(DAYS) & 95.187 & 45.000 & 122.000 & 20.905 & 2.595 & -0.779 \\
\hline ARL(LOG) & 4.526 & 3.810 & 4.800 & 0.253 & 3.295 & -1.145 \\
\hline ACCEXP & 0.655 & 0.000 & 1.000 & 0.477 & 1.423 & -0.651 \\
\hline ACCTENURE & 8.542 & 0.070 & 22.280 & 5.596 & 2.452 & 0.457 \\
\hline ACOVLAP & 0.691 & 0.000 & 1.000 & 0.277 & 2.909 & -0.625 \\
\hline ACIND & 0.906 & 0.500 & 1.000 & 0.146 & 2.500 & -1.055 \\
\hline ACSIZE & 3.295 & 3.000 & 6.000 & 0.619 & 8.159 & 2.286 \\
\hline ACMEET & 5.058 & 3.000 & 10.000 & 1.226 & 5.393 & 1.381 \\
\hline TYPEAUD & 0.525 & 0.000 & 1.000 & 0.501 & 1.010 & -0.101 \\
\hline SIZE(LOG) & 13.152 & 9.880 & 17.675 & 1.451 & 3.169 & 0.516 \\
\hline LEV & 0.194 & 0.000 & 0.724 & 0.165 & 2.816 & 0.595 \\
\hline PROF & 0.052 & -0.496 & 0.379 & 0.097 & 11.689 & -0.782 \\
\hline
\end{tabular}

Notes: To mitigate the influence of outliers, we winsorize PROF at the 1st and the 99th percentiles. 


\subsection{Pearson Correlation Matrix}

Table 4 below depicts the Pearson Correlation of the variables. ARL was found to be significantly and positively linked with ACOVLAP and ACIND, and it was negatively linked with ACCEXP, ACSIZE, TYPEAUD, SIZE, and PROF. No multicollinearity existed between the independent variables as the maximum correlation was found to be 0.420 (between LEV and SIZE). This is suggestive of the notion that the multicollinearity problem is not as severe as the correlation between the variables is less than 0.90 (Hair, Black, Babin, \& Anderson, 2014).

Table 4. Pearson Correlation

\begin{tabular}{|c|c|c|c|c|c|c|c|c|c|c|c|}
\hline Variables & 1 & 2 & 3 & 4 & 5 & 6 & 7 & 8 & 9 & 10 & 11 \\
\hline $1 \mathrm{ARL}$ & 1.000 & & & & & & & & & & \\
\hline 2 ACCEXP & $-0.149 *$ & 1.000 & & & & & & & & & \\
\hline 3 ACCTENURE & 0.010 & $-0.303 * * *$ & 1.000 & & & & & & & & \\
\hline 4 ACOVLAP & $0.201 * *$ & -0.056 & 0.074 & 1.000 & & & & & & & \\
\hline 5 ACIND & $0.295 * * *$ & $-0.137 *$ & 0.113 & $0.205^{* *}$ & 1.000 & & & & & & \\
\hline 6 ACSIZE & $-0.352 * * *$ & 0.077 & -0.084 & -0.124 & $-0.397 * * *$ & 1.000 & & & & & \\
\hline 7 ACMEET & 0.132 & -0.102 & 0.060 & $-0.172 * *$ & $-0.159 *$ & 0.025 & 1.000 & & & & \\
\hline 8 TYPEAUD & $-0.259 * * *$ & 0.006 & 0.048 & -0.055 & $-0.240 * * *$ & $0.198 * *$ & 0.127 & 1.000 & & & \\
\hline 9 SIZE(LOG) & $-0.336^{* * * *}$ & -0.130 & 0.063 & $-0.148 *$ & $-0.154^{*}$ & $0.188^{* *}$ & $0.208 * *$ & $0.409 * * *$ & 1.000 & & \\
\hline $10 \mathrm{LEV}$ & 0.090 & -0.052 & -0.081 & 0.005 & -0.060 & -0.073 & 0.121 & 0.110 & 0.420 *** & 1.000 & \\
\hline 11 PROF & $-0.289 * * *$ & 0.004 & 0.046 & -0.075 & -0.068 & 0.077 & -0.112 & 0.058 & $0.168^{* *}$ & $-0.147^{*}$ & 1.000 \\
\hline
\end{tabular}

Note: $* * * \mathrm{p}<0.01, * * \mathrm{p}<0.05, * \mathrm{p}<0.1$

\subsection{Regression Results}

Results of the linear regression analysis are presented in Table 5. The heteroscedasticity was checked using the Breusch-Pagan test, which was significant at $1 \%$ level. Therefore, the study used a robust regression analysis in which the $\mathrm{R}^{2}$ of the model was 0.385 . This points to the fact that the model explains 38.5 per cent of the variance in the ARL, whereby the model is significant at 1 per cent $(\mathrm{F}$-statistic $=5.678, \mathrm{p}<0.000)$. This further suggests that the variation in ARL is significantly explained by the model.

Next, the results showed a negative relationship between ACC with accounting expertise (ACCEXP) and ARL, which supported the first hypothesis and provided evidence that the ACC with accounting expertise was related to reducing the ARL with significance. This is due to ACC with accounting expertise that elevates the AC ability to ensure the work of the external auditor is fully undertaken, as well as comprehend and mediate the disagreements between corporate management and the auditors, thereby reducing the ARL (Sultana et al., 2015). The findings support the important roles of ACC as shown in prior works (Abernathy et al., 2014; Baatwah et al., 2019; Schmidt \& Wilkins, 2013).

The second hypothesis predicted a negative relationship between the tenure of ACC (ACCTENURE) and the ARL, whereby the result showed a negative relationship that was not significant. This result is consistent with the argument by Vafeas (2003): longer tenure directors are more affiliated and less effective in monitoring. In contrast, this result is at odds with Baatwah et al.'s (2019) outcome of a negative and significant link with ARL.

The third hypothesis predicted a non-directional relationship between AC overlap (ACOVLAP) and ARL, whereas the result showed a positive relationship, which was statistically not significant. This indicates that AC overlap does not affect ARL in Malaysia. Therefore, the insignificant relationship may suggest that no evidence that AC directors who sit on multiple committees may affect their ability to fulfil their duties effectively. This echoes the outcomes of Kusnadi et al. (2016), who find that the overlapping membership of ACs yields no significant impact on the FRQ for companies.

The fourth hypothesis predicted a negative relationship linking AC independence (ACIND) and ARL in which it was not supported. This is in tandem with the findings of Apadore and Mohd-Noor (2013), Mohamad-Nor et al. (2010), and Wan-Hussin et al. (2018), who also find an insignificant relationship. Furthermore, Puasa et al. (2014) have yielded findings showing that the independence level of AC has no influence of significance on ARL after the 
MCCG (Revised 2007) is in effect. In contrast, Wan-Hussin and Bamahros (2013) and Baatwah et al. (2019) have shown a significant relationship between AC independence and ARL. One of the possible reasons behind this finding may be due to the fact that most of the AC consist of independent directors. It is also in line with MCCG requirements for all $\mathrm{AC}$ members to be non-executive directors, with a big chunk of the percentage consists of independent directors. Furthermore, the independence of the AC members is limited to the information divulged by the companies, which may be substantially questioned due to their correlation with the management.

For the control variables, AC size, AC meeting, firm size, leverage, and profitability were found to have a significant effect on ARL. In particular, AC size (ACSIZE) had a negative significance at ten per cent, which implied that companies with a large number of AC members would exert some pressure or demands on the management, hence resulting in a fast-track audit report. Thus, this outcome is in tandem with previous findings (Apadore \& Mohd-Noor, 2013; Mohamad-Nor et al., 2010; Puasa et al., 2014). Meanwhile, the frequency of AC meetings (ACMEET) was positively significant at five per cent. This means that more frequent $\mathrm{AC}$ meetings are related to the highly stringent levels of auditing, thus resulting in longer delays and aligns with Wan-Hussin and Bamahros (2013) and Kamarudin et al. (2018), who have noted that ACs having frequent meetings have a positive relationship with ARL. However, Mohamad-Nor et al. (2010) and Baatwah et al. (2019) have revealed that more frequent AC meetings reduce the ARL.

For the auditor type (TYPEAUD), this study found an insignificant relationship and implied no relationship was present between the type of auditors and ARL. This parallels the findings of Apadore and Mohd-Noor (2013) and Puasa et al. (2014) for the post-MCCG 2007; they have found an insignificant relationship with ARL. Similarly, firm size (SIZE) was negatively associated with ARL, which was consistent with previous studies and implied that large companies were linked with a shorter audit lag. Accordingly, this outcome echoes those obtained by past studies, such as Mohamad Nor et al. (2010), Apadore and Mohd-Noor (2013), and Wan-Hussin et al. (2018).

Next, leverage (LEV) was positively and statistically of significance at five per cent, indicating highly leveraged companies tended to hinder the publication of their yearly reports and yield a prolonged audit lag period. Empirically, this result parallels the results of Puasa et al. (2014) and Al-Ajmi (2008), who have documented that leverage is positively related to the ARL. Meanwhile, profitability (PROF) generated a negative relationship with ARL, which was significant at five per cent. This indicates that companies with higher profitability possibly desires auditing of their accounts to conclude within the shortest time possible in order to quickly divulge the audited corporate annual reports and disseminate the "good news". This result is in line with most of the prior studies, such as Afify (2009), Nelson and Shukeri (2011), and Apadore and Mohd-Noor (2013). Finally, for the variable of industry type (INDUS), this study found an insignificant relationship and indicated no relationship was present between industry type and ARL.

Table 5. Multiple Regression Analysis

\begin{tabular}{|c|c|c|c|}
\hline Variables & Coef. & t-statistics & $p>t$ \\
\hline ACCEXP & -6.408 & -2.00 & $0.048 * *$ \\
\hline ACCTENURE & -0.184 & -0.65 & 0.518 \\
\hline ACOVLAP & 7.132 & 1.24 & 0.217 \\
\hline ACIND & 18.593 & 1.43 & 0.154 \\
\hline ACSIZE & -5.395 & -1.70 & $0.093^{*}$ \\
\hline ACMEET & 3.241 & 2.02 & $0.045^{* *}$ \\
\hline TYPEAUD & -3.633 & -1.16 & 0.249 \\
\hline SIZE & -4.686 & -3.18 & $0.002 * * *$ \\
\hline LEV & 23.387 & 2.26 & $0.026 * *$ \\
\hline PROF & -42.862 & -2.20 & $0.030 * *$ \\
\hline INDUS (dummy) & Included & Included & Included \\
\hline Cons & 143.246 & 4.99 & $0.000 * * *$ \\
\hline $\mathrm{R}^{2}$ & 0.385 & & \\
\hline F-statistics & $5.678 * * *$ & & \\
\hline $\mathrm{N}$ & 139 & & \\
\hline
\end{tabular}




\section{Conclusion}

The main objective positioned by this work was to assess the relationship linking the accounting expertise in the AC and ARL in Malaysia. Accordingly, the outcomes revealed that the accounting expertise of the ACC was negatively and significantly associated with ARL, thereby supporting the argument that ACC with accounting expertise would result in timely audit reports. This further suggests the merit to have ACC with accounting expertise in the case of ARL. Consequently, this study provides evidence to regulators and policymakers in order to consider such attribute of AC as being capable of improving the timeliness of audit report for the purpose of enhancing the FRQ.

Furthermore, by taking the new implementation to reduce the timeframe for annual report issuance in Malaysia into consideration, the outcomes obtained from this study are thus helpful to regulators and policymakers in improving timeframe of such issuance. They successfully provide the potential factors influencing the timeliness of the external auditors to issue the ARL, such as the accounting expertise of the ACC, among others. The improvements in ARL will undoubtedly pose a notable impact on the timeliness of audited financial report issuance, which leads to the improving timeliness of their issuance.

In view of the findings and limitations of this study, future studies may be conducted on the variables that are not covered in this study in order to provide more insight detailing ARL determinants. In particular, the current study used ACC attributes such as accounting expertise and tenure of ACC as the factors that might reduce the ARL in Malaysia. Hence, future study is suggested to incorporate other variables that may have an impact on ARL, such as the other attributes of ACC (e.g. age as a proxy of experience) and AC chairman former audit partner. Future research can also contribute to the body of knowledge by utilising several factors of the board and AC attributes in order to develop an effectiveness index. Moreover, this study included data obtained according to the annual reports of 2015. Thus, future studies may be conducted to analyse the influence of corporate governance features on ARL by using the data of pre- and post-revised MCCG code 2017. Additionally, future studies can be extended by replicating this study using both financial and non-financial listed companies.

\section{References}

Abbott, L. J., Park, Y., \& Parker, S. (2000). The effects of audit committee activity and independence on corporate fraud. Managerial Finance, 26(11), 55-68.

Abbott, L. J., Parker, S., \& Peters, G. F. (2004). Audit committee characteristics and restatements. Auditing: A Journal of Practice \& Theory, 23(1), 69-87.

Abbott, L. J., Parker, S., \& Peters, G. F. (2012). Internal audit assistance and external audit timeliness. Auditing: A Journal of Practice \& Theory, 31(4), 3-20.

Abdul Latif, R., Kamardin, H., Taufil Mohd, K., \& Che Adam, N. (2013). Multiple directorships, board characteristics and firm performance in Malaysia. Management, 3(2), 105-111.

Abdullah, S.-N. (2006). Board composition, audit committee and timeliness of corporate financial reports in Malaysia. Corporate Ownership and Control, 4(2), 24-32.

Abernathy, J. L., Beyer, B., Masli, A., \& Stefaniak, C. (2014). The association between characteristics of audit committee accounting experts, audit committee chairs, and financial reporting timeliness. Advances in Accounting, 30(2), 283-297.

Abernathy, J. L., Beyer, B., Masli, A., \& Stefaniak, C. M. (2015). How the source of audit committee accounting expertise influences financial reporting timeliness. Current Issues in Auditing, 9(1), P1-P9.

Afify, H. A. E. (2009). Determinants of audit report lag: Does implementing corporate governance have any impact? Empirical evidence from Egypt. Journal of Applied Accounting Research, 10(1), 56-86.

Ahmed, M. I. M. I., \& Che-Ahmad, A. (2016). Effects of corporate governance characteristics on audit report lags. International Journal of Economics and Financial Issues, 6(7S), 159-164.

Al-Absy, M. S. M., Ismail, K. N. I. K., \& Chandren, S. (2018). Accounting expertise in the audit committee and earnings management. Business and Economic Horizon, 14(3), 451-476.

Al-Absy, M. S. M., Ismail, K. N. I. K., \& Chandren, S. (2019). Audit committee chairman characteristics and earnings management. Asia-Pacific Journal of Business Administration, 11(4), 339-370.

Al-Ajmi, J. (2008). Audit and reporting delays: Evidence from an emerging market. Advances in Accounting, 24(2), $217-226$. 
Alfraih, M. M. (2016). Corporate governance mechanisms and audit delay in a joint audit regulation. Journal of Financial Regulation and Compliance, 24(3), 292-316.

AlQadasi, A., \& Abidin, S. (2018). The effectiveness of internal corporate governance and audit quality: The role of ownership concentration-Malaysian evidence. Corporate Governance: The International Journal of Business in Society., 18(2), 233-253.

AlQadasi, A., Abidin, S., \& Al-Jaifi, H. A. (2018). The puzzle of internal audit function budget toward specialist auditor choice and audit fees: Does family ownership matter? Malaysian evidence. Managerial Auditing Journal, 34(2), 208-243.

Apadore, K., \& Mohd-Noor, M. (2013). Determinants of audit report lag and corporate governance in Malaysia. International Journal of Business and Management, 8(15), 151-163.

Ashton, R. H., Graul, P. R., \& Newton, J. D. (1989). Audit delay and the timeliness of corporate reporting. Contemporary Accounting Research, 5(2), 657-673.

Ashton, R. H., Willingham, J. J., \& Elliott, R. K. (1987). An empirical analysis of audit delay. Journal of Accounting Research, 25(2), 275-292.

Baatwah, S., Ahmad, N., \& Salleh, Z. (2013). Whether audit committee financial expertise is the only relevant expertise: A review of audit committee expertise and timeliness of financial reporting. Issues in Social and Environmental Accounting, 7(2), 86-101.

Baatwah, S. R., Ahmad, N., \& Salleh, Z. (2016). Audit committee financial expertise and financial reporting timeliness in emerging market: Does audit committee chair matter? Issues in Social \& Environmental Accounting, 10(4).

Baatwah, S. R., Salleh, Z., \& Ahmad, N. (2015). CEO characteristics and audit report timeliness: Do CEO tenure and financial expertise matter? Managerial Auditing Journal, 30(8/9), 998-1022.

Baatwah, S. R., Salleh, Z., \& Stewart, J. (2019). Audit committee chair accounting expertise and audit report timeliness: The moderating effect of chair characteristics. Asian Review of Accounting, 27(2), 273-306.

Bamber, E. M., Bamber, L. S., \& Schoderbek, M. P. (1993). Audit structure and other determinants of audit reporting: An empirical analysis. Auditing; A Journal of Practice and Theory, 12(1), 1-23.

Bardos, K. S. (2011). Quality of financial information and liquidity. Review of Financial Economics, 20(2), 49-62.

Bedard, J., Chtourou, S. M., \& Courteau, L. (2004). The effect of audit committee expertise, independence, and activity on aggressive earnings management. Auditing: A Journal of Practice \& Theory, 23(2), 13-35.

Bhuiyan, M. B. U., \& D'Costa, M. (2020). Audit committee ownership and audit report lag: Evidence from Australia. International Journal of Accounting \& Information Management, 28(1), 96-125.

Blankley, A. I., Hurtt, D. N., \& MacGregor, J. E. (2014). The relationship between audit report lags and future restatements. Auditing: A Journal of Practice \& Theory, 33(2), $27-57$.

Byrd, J., Cooperman, E. S., \& Wolfe, G. A. (2010). Director tenure and the compensation of bank CEOs. Managerial Finance, 36(2), 86-102.

Carcello, J. V., Hollingsworth, C. W., Klein, A., \& Neal, T. L. (2006). Audit committee financial expertise, competing corporate governance mechanisms, and earnings management. Available at SSRN: https://ssrn.com/abstract=1280676.

Carslaw, C. A., \& Kaplan, S. E. (1991). An examination of audit delay: Further evidence from New Zealand. Accounting and Business Research, 22(85), 21-32.

Chan, A. M. Y., Liu, G., \& Sun, J. (2012). Independent audit committee members ' board tenure and audit fees. Accounting \& Finance, 53(4), 1129-1147.

Chan, K. H., Luo, V. W., \& Mo, P. L. L. (2016). Determinants and implications of long audit reporting lags: Evidence from China. Accounting and Business Research, 46(2), 145-166.

Chandar, N., Chang, H., \& Zheng, X. (2012). Does overlapping membership on audit and compensation committees improve a firm's financial reporting quality? Review of Accounting and Finance, 11(2), 141-165.

Che-Ahmad, A., \& Abidin, S. (2008). Audit delay of listed companies: A case of Malaysia. International Business Research, 1(4), 32-39. 
CLSA and ACGA. (2016). CG Watch 2016: Ecosystems matter. Retrieved from https://www.acga-asia.org/upload/files/research_preview/20161014021202_3.pdf

Courtis, J. K. (1976). Relationships between timeliness in corporate reporting and corporate attributes. Accounting and Business Research, 7(25), 45-56.

Daoud, K. A. Al, Ismail, K. N. I. K., \& Lode, N. A. (2015). The impact of internal corporate governance on the timeliness of financial reports of Jordanian firms: Evidence using audit and management report lags. Mediterranean Journal of Social Sciences, 6(1), 430.

DeFond, M. L., Hann, R. N., \& Hu, X. (2005). Does the market value financial expertise on audit committees of boards of directors? Journal of Accounting Research, 43(2), 153-193.

Dhaliwal, D. A. N., Naiker, V. I. C., \& Navissi, F. (2010). The association between accruals quality and the characteristics of accounting experts and mix of expertise on audit committees. Contemporary Accounting Research, 27(3), 787-827.

Dong, B., Robinson, D., \& Xu, L. (Emily). (2018). Auditor-client geographic proximity and audit report timeliness. Advances in Accounting, 40(December 2017), 11-19.

Durand, G. (2019). The determinants of audit report lag: A meta-analysis. Managerial Auditing Journal, 34(1), 44-75.

Dyer, J. C., \& McHugh, A. J. (1975). The timeliness of the Australian annual report. Journal of Accounting Research, 13(2), 204.

Ghafran, C., \& Yasmin, S. (2018). Audit committee chair and financial reporting timeliness: A focus on financial, experiential and monitoring expertise. International Journal of Auditing, 22(1), 13-24.

Ghaleb, B. A. A., Kamardin, H., \& Tabash, M. I. (2020). Family ownership concentration and real earnings management: Empirical evidence from an emerging market. Cogent Economics and Finance, 8(1).

Ghazali, Z., \& Manab, N. A. N. (2013). The effect of Malaysian code of corporate governance (MCCG) implementation to companies' performances. Journal of Accounting, Finance and Economics, 3(2), 43-52.

Gilling, D. M. (1977). Timeliness in corporate reporting: Some further comment. Accounting and Business Research, 8(29), 34-36.

Givoly, D., \& Palmon, D. (1982). Timeliness of annual earnings announcements: Some empirical evidence. The Accounting Review, 57(3), 486-508.

Habib, A. (2015). The new Chinese accounting standards and audit report lag. International Journal of Auditing, 19(1), 1-14.

Habib, A., \& Bhuiyan, M. B. U. (2011). Audit firm industry specialization and the audit report lag. Journal of International Accounting, Auditing and Taxation, 20(1), 32-44.

Habib, A., \& Bhuiyan, M. B. U. (2016). Overlapping membership on audit and compensation committees and financial reporting quality. Australian Accounting Review, 26(1), 76-90.

Habib, A., Bhuiyan, M. B. U., Huang, H. J., \& Miah, M. S. (2019). Determinants of audit report lag: A meta-analysis. International Journal of Auditing, 23(1), 20-44.

Habib, A., \& Muhammadi, A. H. (2018). Political connections and audit report lag: Indonesian evidence. International Journal of Accounting \& Information Management, 26(1), 59-80.

Hair, J. F., Black, W. C., Babin, B. J., \& Anderson, R. E. (2014). Multivariate Data Analysis.

Hashim, U. J. B., \& Rahman, R. B. A. (2011). Audit report lag and the effectiveness of audit committee among Malaysian listed companies. International Bulletin of Business Administration, 10(10), 50-61.

Hasnan, S., \& Hussain, A. R. M. (2015). Factors associated with financial restatements: Evidence from Malaysia. Jurnal Pengurusan (UKM Journal of Management), 44.

Hassan, Y. M. (2016). Determinants of audit report lag: Evidence from Palestine. Journal of Accounting in Emerging Economies, 6(1), 13-32.

Herranz, C. Z., Iturriaga, F. J. L., \& Reguera-Alvarado, N. (2018). The right person at the right time: Audit committee members and the quality of financial information. Universia Busines Review, 58, 18-35. 
Hillman, A. M. Y. I., \& Dalziel, T. (2003). Boards of directors and firm performance: Integrating agency and resource dependence perspectives. Academy of Management Review, 28(3), 383-396.

Juwita, R., T, S., \& Hariadi, B. (2020). Influence of audit committee and internal audit on audit report lag : Size of public accounting firm as a moderating variable. Research in Business \& Social Science, 9(1), 137-142.

Kaaroud, M. A., Mohd Ariffin, N., \& Ahmad, M. (2020). The extent of audit report lag and governance mechanisms. Journal of Islamic Accounting and Business Research, 11(1), 70-89.

Kamardin, H., \& Haron, H. (2011). Internal corporate governance and board performance in monitoring roles. Journal of Financial Reporting and Accounting, 9(2), 119-140.

Kamarudin, K. A., Ismail, W. A. W., Yaacob, Z., \& Bakar, S. S. A. (2018). Auditor specialization and its influence on the association between governance and the timeliness of financial reporting. In State-of-the-Art Theories and Empirical Evidence (pp. 93-106).

Karim, K., Robin, A., Suh, S., Khondkar, K., Robin, A., \& Suh, S. (2016). Board structure and audit committee monitoring: Effects of audit committee monitoring incentives and board entrenchment on audit fees. Journal of Accounting, Auditing \& Finance, 31(2), 249-276.

Kesner, I. F. (1988). Directors' characteristics and committee membership: An investigation of type, occupation, tenure, and gender. Academy of Management Journal, 31(1), 66-84.

Khlif, H., \& Samaha, K. (2014). Internal control quality, Egyptian standards on auditing and external audit delays: Evidence from the Egyptian Stock Exchange. International Journal of Auditing, 18(2), 139-154.

Knechel, W. R., Sharma, D. S., \& Sharma, V. D. (2012). Non-audit services and knowledge spillovers: Evidence from New Zealand. Journal of Business Finance \& Accounting, 39(1-2), 60-81.

Krishnan, G. V., \& Visvanathan, G. (2008). Does the SOX definition of an accounting expert matter? The association between audit committee directors' accounting expertise and accounting conservatism. Contemporary Accounting Research, 25(3), 827-858.

Kusnadi, Y., Leong, K. S., Suwardy, T., \& Wang, J. (2016). Audit committees and financial reporting quality in Singapore. Journal of Business Ethics, 139(1), 197-214.

Lee, H.-Y., \& Jahng, G.-J. (2011). Determinants of audit report lag: Evidence from Korea-an examination of auditor-related factors. Journal of Applied Business Research (JABR), 24(2), 27-44.

Lee, H.-Y., Mande, V., \& Son, M. (2009). Do lengthy auditor tenure and the provision of non-audit services by the external auditor reduce audit report lags? International Journal of Auditing, 13(2), 87-104.

Leventis, S., Weetman, P., \& Caramanis, C. (2005). Determinants of audit report lag: Some evidence from the Athens Stock Exchange. International Journal of Auditing, 9(1), 45-58.

Liao, C.-H. H., \& Hsu, A. W.-H. H. (2013). Common Membership and Effective Corporate Governance: Evidence from Audit and Compensation Committees. Corporate Governance: An International Review, 21(1), 79-92.

Liu, G., \& Sun, J. (2010). Director tenure and independent audit committee effectiveness. International Research Journal of Finance \& Economics, 51(51), 176-189.

Mande, V., \& Son, M. (2011). Do audit delays affect client retention? Managerial Auditing Journal, 26(1), 32-50.

Meckfessel, M. D., \& Sellers, D. (2017). The impact of Big 4 consulting on audit reporting lag and restatements. Managerial Auditing Journal, 32(1), 19-49.

Mohamad-Nor, M. N., \& Ishak, S. (2017). Corporate governance and risk management in Malaysia. In 8th International Conference of The Asian Academy of Applied Business (AAAB) 2017.

Mohamad-Nor, M. N., Shafie, R., \& Wan-Hussin, W. N. (2010). Corporate governance and audit report lag. Asian Academy of Management Journal of Accounting and Finance, 6(2), 57-84.

MohammadRezaei, F., \& Mohd-Saleh, N. (2018). Audit report lag: The role of auditor type and increased competition in the audit market. Accounting \& Finance, 58(3), 885-920.

Nelson, S. P., \& Shukeri, S. N. (2011). Corporate governance and audit report timeliness: Evidence from Malaysia. In Research in Accounting in Emerging Economies (pp. 109-127). Emerald Group Publishing Limited.

Oussii, A. A., \& Taktak, N. B. (2018). Audit committee effectiveness and financial reporting timeliness. African Journal of Economic and Management Studies, 9(1), 34-55. 
Owusu-Ansah, S., \& Leventis, S. (2006). Timeliness of corporate annual financial reporting in Greece. European Accounting Review, 15(2), 273-287.

Ponnu, C. H. (2008). Corporate governance structures and the performance of Malaysian public listed companies. International Review of Business Research Papers, 4(2), 217-230.

Puasa, S., Salleh, M. F. M., \& Ahmad, A. (2014). Audit committee and timeliness of financial reporting: Malaysian public listed companies. Middle-East Journal of Scientific Research, 22(2), 162-175.

Qasem, A., Aripin, N., \& Wan-Hussin, W. N. (2020). Financial restatements and sell-side analysts' stock recommendations: Evidence from Malaysia. International Journal of Managerial Finance, 16(4), 501-524.

Raja-Ahmad, R. A., \& Kamarudin, K. A. (2003). Audit delay and the timeliness of corporate reporting: Malaysian evidence. In Communication Hawaii International Conference on Business. University of Hawaii-West Oahu.

Raweh, N. A. M., Kamardin, H., \& Malik, M. (2019). Audit committee characteristics and audit report lag : Evidence from Oman. International Journal of Accounting and Financial Reporting, 9(1), 152-169.

Rickling, M. (2014). Audit committee characteristics and repeatedly meeting-beating analyst forecasts. International Journal of Business, 19(2), 173-191.

Rusmin, R., \& Evans, J. (2017). Audit quality and audit report lag: Case of Indonesian listed companies. Asian Review of Accounting, 25(2), 191-210.

Salleh, K., \& Jasmani, H. (2014). Audit rotation and audit report: Empirical evidence from Malaysian PLCs over the period of ten years. Procedia - Social and Behavioral Sciences, 145, 40-50.

Schmidt, J., \& Wilkins, M. S. (2013). Bringing darkness to light: The influence of auditor quality and audit committee expertise on the timeliness of financial statement restatement disclosures. Auditing: A Journal of Practice \& Theory, 32(1), 221-244.

Securities Commission.(2000). Malaysian Code on Corporate Governance 2000. Retrieved from http://www.ecgi.org/codes/documents/mccg_mar2000.pdf

Securities Commission.(2007). Malaysian Code on Corporate Governance (Revised 2007). Retrieved from http://www.ecgi.org/codes/documents/cg_code_malaysia_2007_en.pdf.

Securities Commission.(2012).Malaysian Code on Corporate Governance 2012. Retrieved from http://micg.org.my/upload/file/articles/11/CODE-CG-2012.pdf

Securities Commission.(2017).Malaysian Code on Corporate Governance 2017. Retrieved from https://www.sc.com.my/wp-content/uploads/eng/html/cg/mccg2017.pdf

Securities Commission.Proposed Draft of the Malaysian Code on Corporate Governance 2016. Retrieved from https://www.sc.com.my/api/documentms/download.ashx?id=c449b0b3-0338-4270-aeea-122d31aa8d28

Shafie, R., Wan-Hussin, W. N., Yusof, M. A. M., \& Hussain, M. H. (2009). Audit firm tenure and auditor reporting quality: Evidence in Malaysia. International Business Research, 2(2), 99-109.

Sharma, D. S., Tanyi, P. N., \& Litt, B. A. (2017). Costs of mandatory periodic audit partner rotation: Evidence from audit fees and audit timeliness. Auditing: A Journal of Practice \& Theory, 36(1), 129-149.

Shin, I. H., Lee, H. Y., Lee, H. A., \& Son, M. (2017). How does human resource investment in internal control affect audit reporting lag? Asia-Pacific Journal of Accounting \& Economics, 24(1-2), 195-215.

Singam, K. (2003). Corporate governance in Malaysia. Bond Law Review (Vol. 15).

Soltani, B. (2002). Timeliness of corporate and audit reports. The International Journal of Accounting, 37(2), $215-246$.

Song, J., \& Windram, B. (2004). Benchmarking audit committee effectiveness in financial reporting. International Journal of Auditing, 8(3), 195-205.

Steffens, N. K., Shemla, M., Wegge, J., \& Diestel, S. (2014). Organizational tenure and employee performance. Group \& Organization Management, 39(6), 664-690.

Sultana, N., Singh, H., \& Van der Zahn, J. L. M. (2015). Audit committee characteristics and audit report lag. International Journal of Auditing, 19(2), 72-87.

Sultana, N., \& Van der Zahn, J. L. M. (2015). Earnings conservatism and audit committee financial expertise. 
Accounting \& Finance, 55(1), 279-310.

Swanson, Z., \& Zhang, Y. (2018). Do covenant violations affect audit report timeliness ? International Journal of Accounting, Auditing and Performance Evaluation, 14(1), 1-23.

Tanyi, P. N., \& Smith, D. B. (2015). Busyness, expertise, and financial reporting quality of audit committee chairs and financial experts. Auditing: A Journal of Practice \& Theory, 34(2), 59-89.

Thoopsamut, W., \& Jaikengkit, A. (2009). Audit committee characteristics, audit firm size and quaterly earnings management in Thailand. In Emerging Issues and Challenges in Business \& Economics: Selected Contributions from the 8th Global Conference (Vol. 24, p. 47). Firenze University Press.

Udueni, H. (1999). Power dimensions in the board and outside director independence: Evidence from large industrial UK firms. Corporate Governance, 7(1), 62-72.

Vafeas, N. (2003). Length of board tenure and outside director independence. Journal of Business Finance \& Accounting, 30(7-8), 1043-1064.

Varici, I. (2013). The relationship between information asymmetry and the quality of audit: An empirical study in Istanbul Stock Exchange. International Business Research, 6(10), 132-140.

Velte, P. (2017). Do overlapping audit and compensation committee memberships contribute to better financial reporting quality? Empirical evidence for the German two-tier system. International Journal of Economics and Accounting, 8(3/4), 196-214.

Vichitsarawong, T., Eng, L. L., \& Meek, G. K. (2010). The impact of the Asian financial crisis on conservatism and timeliness of earnings: Evidence from Hong Kong, Malaysia, Singapore, and Thailand. Journal of International Financial Management \& Accounting, 21(1), 32-61.

Wan-Hussin, W. N., \& Bamahros, H. M. (2013). Do investment in and the sourcing arrangement of the internal audit function affect audit delay? Journal of Contemporary Accounting \& Economics, 9(1), 19-32.

Wan-Hussin, W. N., Bamahros, H. M., \& Shukeri, S. N. (2018). Lead engagement partner workload, partner-client tenure and audit reporting lag. Managerial Auditing Journal, 33(3), 246-266.

Xu, H., Dao, M., \& Petkevich, A. (2019). Political corruption and auditor behavior: Evidence from US firms. European Accounting Review, 28(3), 513-540.

Xu, Y., Carson, E., Fargher, N., \& Jiang, L. (2013). Responses by Australian auditors to the global financial crisis. Accounting \& Finance, 53(1), 301-338.

Yang, J. S., \& Krishnan, J. (2005). Audit committees and quarterly earnings management. International Journal of Auditing, 9(3), 201-219. 